\title{
What makes a happy face? Determinants of colour pattern in the Hawaiian happy face spider Theridion grallator (Araneae, Theridiidae)
}

\author{
Rosemary G. Gillespie* and \\ Bruce E. Tabashnik
}

Department of Entomology, University of Hawaii, Honolulu, HI 96822.

Theridion grallator, a small $(<5 \mathrm{~mm})$ spider endemic to wet and mesic forests of Hawaii, is highly polymorphic in its abdominal colour pattern. Morphs were either translucent yellow (the background colour only; no pattern) or exhibited superimposed pigmentation. These latter, patterned morphs were grouped into eight major categories, including opaque white and various configurations of red, black or maroon. The unpatterned morph was the most morph common among immatures (69 per cent), mature males (62 per cent) and mature females (62 per cent). All spiderlings were initially unpatterned; patterns developed at 10 to $>100$ days after hatching. Time required for completion of pattern development was roughly proportional to the amount of red in the final pattern. Mature males and females had similar morph frequencies overall, yet three rare morphs were seen only in females. Phenotypic frequencies of families were consistent with Mendelian inheritance at one locus, with the allele dictating absence of pattern recessive to alleles for patterned morphs.

\section{INTRODUCTION}

Discontinuous phenotypic variation is a widespread phenomenon in the animal kingdom. Polymorphism, in its broadest sense, refers to the occurrence of several strikingly different, discontinuous phenotypes within a single interbreeding population (Mayr, 1970). Numerous cases of chromatic polymorphism have been documented (Clarke et al., 1978; Turner, 1977; Bishop and Cook, 1980). This may be because their expression is more readily observable; or, alternatively, the alleles involved may be more free to vary than those controlling structure.

Colour polymorphism is a widespread phenomenon in spiders. Different morphs have been described in many species, particularly in the family Theridiidae (Theridion frondeum (Comstock, 1948), T. melanostictum, T. gonygaster and species in the genera Chrysso (Levi, personal communication) and Latrodectus (Maretic, 1965; Raven, personal communication)). Polymorphisms have also been noted in other families,

\footnotetext{
* Present address: Department of Biology, The University of the South, Sewanee, TN 37375.
}

including Araneidae (Emerit, 1969, 1973), Tetragnathidae (Levi, 1981), Linyphiidae (Gunnarsson, 1987), Oxyopidae (Brady, 1964), Pisauridae (Davies and Raven, 1980; Yaginuma, 1986; Blandin, 1977), Salticidae (Galiano, 1981) and Gnaphosidae (Platnick and Shadab, 1975).

There is little known about the genetic basis of most spider polymorphisms. The colour polymorphism in Enoplognatha ovata (Araneae, Theridiidae) is a notable exception, and has been thoroughly investigated. Three distinct morphs have been described according to abdominal colouration (Locket and Millidge, 1951; Hippa and Oksala, 1979; Oxford, 1976): lineata (all yellow), redimita (yellow with two dorsolateral carmine stripes), and ovata (yellow with a solid shield of carmine on the dorsal surface). Breeding experiments have shown that the colour pattern variation in E. ovata is genetically determined, although the colour may not appear until individuals reach maturity (Hippa and Oksala, 1979; Oxford, 1983, 1985; Reillo and Wise, 1988a). There appears to be a hierarchy in the phenotypic expression of colour pattern in mature individuals, with ovata dominant over redimita, and lineata recessive to both. This means that, in common with most 
invertebrate colour polymorphisms (Ford, 1975), the dominance hierarchy of $E$. ovata follows the inverse of morph frequencies in nature, i.e., the least dominant (or most recessive) allele is most frequent; the most dominant is the rarest. For the mode of inheritance of the polymorphism in $E$. ovata, Oxford (1983) has proposed a two locus model: one locus is concerned with pattern and colour, the other with the regulation of this colour locus during development. When red-pigmented alleles are linked to the late developing allele, the colour morphs are sex-limited: males are lineata no matter which allele they carry.

$E$. ovata also exhibits much additional variation beyond the three main morph types, including variation in number of dorsolateral black spots and lines, width and shape of red pigmented areas in redimita and ovata, and background colour. Reillo (personal communication, Reillo and Wise, $1988 b$ ) has found that at least some of these patterns are genetic. This additional variability (i.e., distinct from the main patterns) may be polygenic, as in the inheritance of dark colouration in the linyphiid spider Pityohyphantes phrygianus (Gunnarsson, 1987).

The only other spiders in which the mode of inheritance of the polymorphism has been examined are species of the genus Phiale ( $P$. tristis, $P$. mimica, $P$. crocea and $P$. ortrudae) in the family Salticidae. Galiano (1981) demonstrated that colour patterns in these highly polymorphic species are inherited as simple Mendelian alleles. The polymorphism appears to be sex-limited: males are monomorphic and females polymorphic. Nothing is yet known of its significance or possible adaptive value.

The present study examined the colour polymorphism in the Hawaiian happy face spider, Theridion grallator (Araneae, Theridiidae), a resident of the underside of leaves in wet and mesic forests of Hawaii. This species exhibits much variability in abdominal colouration (Gon, 1985), which was investigated in four stages: 1 . Description of categories of abdominal colouration. 2. Morph frequencies of mature males and females, and immatures. 3. Ontogenetic changes in colour pattern. Using this information, we could investigate: 4 . inheritance of the different morphs. We tested the mode of inheritance of the polymorphism in $T$. grallator to find out whether or not it was similar to that of $E$. ovata, with the most frequent morph under the control of a recessive allele, and different patterned morphs a result of a dominance hierarchy of alleles at a single locus.

\section{METHODS}

The Hawaiian happy face spider, $T$. grallator, is a small $(<5 \mathrm{~mm})$ endemic resident of wet and mesic forests of Hawaii (Gon, 1985). It has long, slender legs and a smooth translucent yellow body. The abdomen may have pigment of red, maroon, black or white; the amount and pattern of pigment varies greatly among individuals. The spider inhabits the underside of leaves of a variety of plants, especially the native Broussaisia arguta and Clermontia arborescens, and also the introduced white ginger, Hedychium coronarium. Generally, except for maternal females and offspring, a single individual only is found on a leaf. Maternal females and their spiderlings remain as a family unit for 40 to 100 days, after which the spiderlings disperse. $T$. grallator is highly seasonal. Very small spiders and immatures predominate in the winter months. Adults dominate the populations in spring, so that, by May, the bulk of the population consists of females with egg sacs.

The study was conducted in the Nature Conservancy of Hawaii's Waikamoi Preserve on Maui, near the common boundary of the Preserve and the Makawao State Forest at $1360 \mathrm{~m}$ elevation. Populations of $T$. grallator occur primarily on the discrete stands of $B$. arguta and $C$. arborescens in native forest (mixed Ohi'a-Koa). Spiders were located by thorough scrutiny of the leaves of these plants in two sites of about 0.5 hectares each.

\section{Description of categories of abdominal colouration}

All individuals found during the study were described and categorized into morph types.

\section{Morph frequencies}

The colour and size of individuals on the leaves were recorded at two sites (both approximately $5000 \mathrm{~m}^{2}$ and separated by approximately $300 \mathrm{~m}$ ) in independent samples conducted every two weeks from September 1987 until August 1988. This allowed an estimate of the frequency of the different morphs and their spatial variability. Immatures were counted after dispersal from the maternal leaf (40-100 days after hatching). Immatures were scored in the size classes: 1$2 \mathrm{~mm}, 2-3 \mathrm{~mm}, 3-4 \mathrm{~mm}$. Adult patterns were also recorded, mature animals being recognized by palpal development in the male, reproductive state (gravid or maternal) in the female. 


\section{Ontogenetic changes}

Broods of spiderlings were monitored every 2-3 days while they remained on the maternal leaf. To allow identification of individuals, spiderlings were marked with a small dot of paint on one of their legs (re-marked after moulting). Changes in colour pattern over time were recorded.

\section{Inheritance of colour pattern}

Inheritance of colour pattern was examined by enclosing individual females (found from October 1987 to July 1988) with their egg sacs in cheesecloth bags in the field, and rearing their progeny. Paternity for the broods could not be determined because males court with many females, and females may share a leaf with several males. Further, there was no direct evidence that copulation by any particular male was successful.

Offspring were reared from 27 females; egg sacs of 10 additional females (five unpatterned, one white, two red lines, one red $U$ on anterior and posterior dorsum and one red ring) were lost through parasitism or predation. The colour of the offspring was recorded at two- to three-day intervals from the time they hatched until they dispersed. The hypotheses here were that either: (1) the different morphs of $T$. grallator are controlled in a manner similar to those of $E$. ovata, with the most frequent morph under the control of a recessive allele; or (2) the most frequent morph is under the control of a dominant allele. These alternatives were tested using the results from morph frequency estimations to generate predictions as to proportions of different morphs in the offspring of a given female, by means of the Hardy-Weinberg equilibrium.

\section{RESULTS}

\section{Description of categories of abdominal colouration}

Theridion grallator exhibits extraordinary variability in colour patterns on the dorsum of its abdomen, but these can be grouped into unpatterned and eight major patterned categories (fig. 1): (0) No pattern; the background colour of the abdomen is translucent yellow with black dots. The black dots are highly variable in number and extent, but this variability will not be considered here. (1) Opaque white covering the entire abdomen, sometimes with a red-bordered black stripe in the central region. (2) A pair of red patches on the posterior dorsum of the abdomen, sometimes bordered with black. (3) A red "U" (half moon) on the posterior dorsum of the abdomen, of ten bordered with black. (4) A red "U" (half moon) on the anterior dorsum of the abdomen, often bordered with black. (5) A. pair of red lines running down either side of the abdomen; these may also have a black border. (6) A red "U" (half moon) on both the anterior and posterior dorsum of the abdomen; again, these are often bordered with black. (7) A ring of red (sometimes black or maroon), of variable thickness, around the abdomen. (8) An entirely red (sometimes black or maroon) dorsal surface, often with a black line in the central region.

\section{Morph frequencies}

The most common morph was unpatterned (translucent yellow with small black dots, 0 ), this single morph comprising approximately $2 / 3 \mathrm{rds}$ of the population (table 1 ). The remaining morphs (1-8) were patterned, the most frequent of these being (4): red "U" on the anterior dorsum. This morph comprised 12.0 per cent of the population. Morph frequencies did not differ significantly between the two populations, the most common morph comprising 66.6 per cent $(n=952)$ of one population, 69.7 per cent $(n=676)$ of the other (Chi-squared test: $\chi^{2}=1 \cdot 74$, $\left.\mathrm{df}=1, P>0 \cdot 10\right)$.

The percentage of unpatterned morphs was virtually identical for mature males $(62.0$ per cent) and females $(62 \cdot 2$ per cent) (Chi-squared test: $\left.\chi^{2}=0.006, \quad \mathrm{df}=1, \quad P=0 \cdot 90\right)$. Three morphs (opaque white [1], four females only; red patches [2] and red "U" on the posterior dorsum [3], one female only) were seen in mature females, but not in males. These three morphs may be sex-limited. Also, red over the entire abdomen [8] was found in six females, but only a single male. These are, however, rare morphs as a whole, and the results show no significant effects of sex-limitation.

Comparing morph frequencies of mature animals with those of immatures, there was a slight difference between the relative proportion of unpatterned to patterned morphs, perhaps because some of the very small spiders (1-2 mm) were counted prior to development of pattern, and were therefore scored as unpatterned. The difference was significant (Chi-squared test: $\chi^{2}=6 \cdot 12, \mathrm{df}=1$, $P<0.05)$. Considering patterned morphs only, there was a highly significant difference in frequencies of the different morphs (Chi-squared test: $\left.\chi^{2}=129 \cdot 74, \mathrm{df}=11, \quad P<0.0001\right)$. The main differences were in the frequencies of pigment rings and pigment over the entire abdomen (fig. 2): no 


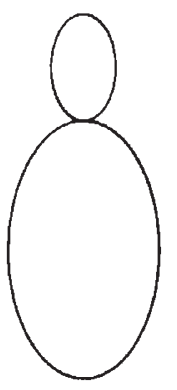

0. Unpatterned

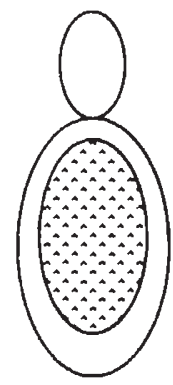

1. Opaque white

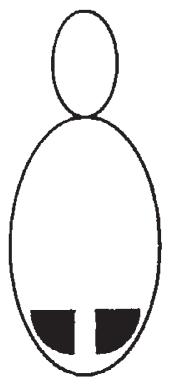

2. Red patches at back

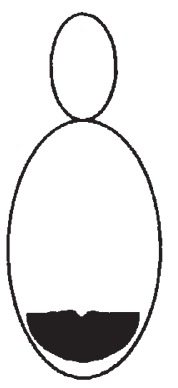

3. Red $U$ at back

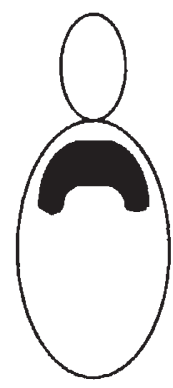

4. Red $U$ at front
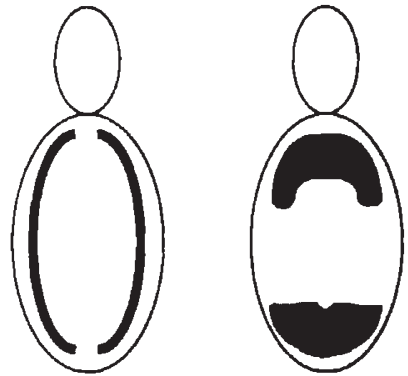

5. Red lines

6. Red $U$ at front and back
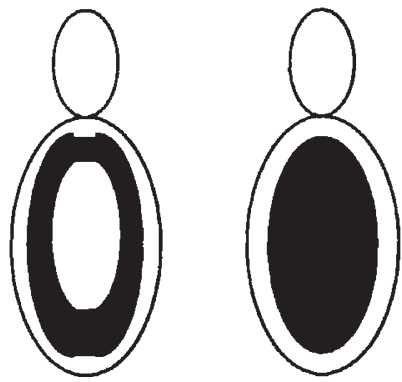

7. Ping

8. Entire abdomen pigmented

(these two morphs black. maroon or red)

Figure 1 Colour patterns of Theridion grallator. Light shading indicates opaque white; dark is black, maroon or red.

Table 1 Frequency of morph types in Waikamoi

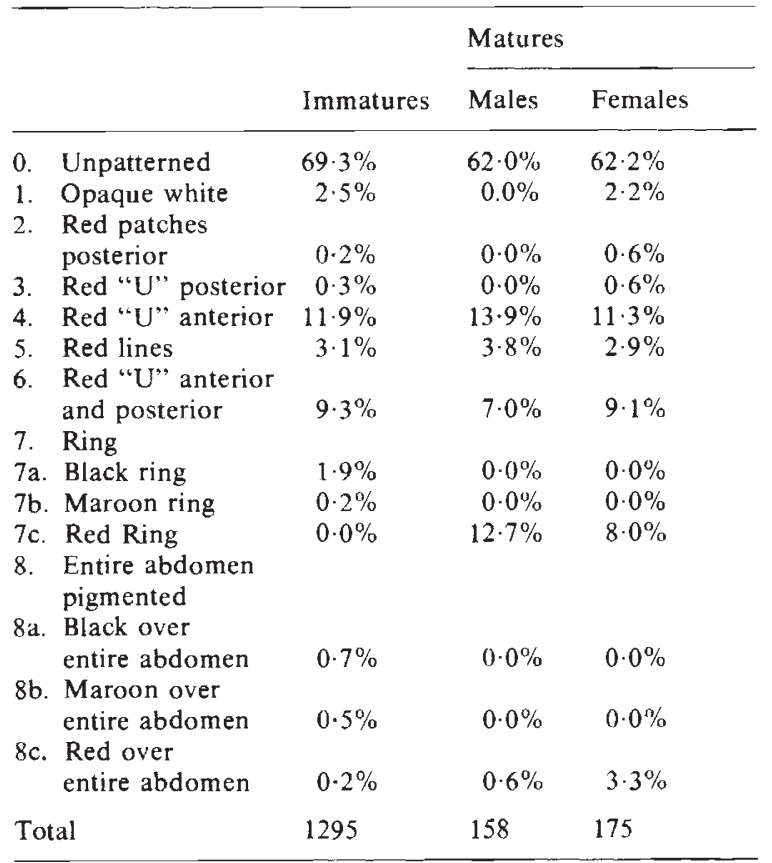

mature animals had black or maroon patterns. Also, the frequency of red over the entire abdomen (8) was much higher in mature animals. These results suggested that black and maroon patterns developed into red patterns as individuals matured.

\section{Ontogenetic changes}

When spiderlings hatched, they were all unpatterned. Patterned morphs varied considerably in the time at which pigment was first seen, as well as the period over which the final pattern developed (table 2). Opaque white was the earliest and quickest to form. Red "U" on the posterior dorsum appeared after about 15 days, and took about a week to develop completely. Red "U" on the anterior dorsum took a little longer ( 24 days) to first appear, with one week more until it was fully developed. Red "U" on both the anterior and posterior dorsum took still longer (30 days) to first appear, again with one week more until it was fully developed. Each of these three red morphs started off with a pattern of red with well defined black 


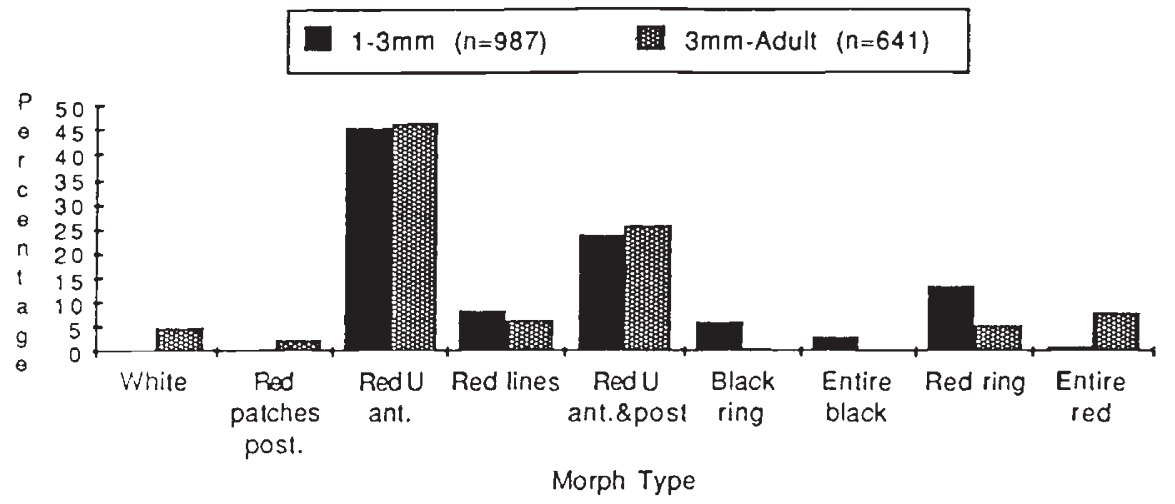

Figure 2 Frequency of patterned morphs in different size classes.

Table 2 Pigment deposition time in various morphs. A number $(n)$ of broods were checked every 2-3 days to examine the time course of colour pattern development

\begin{tabular}{lcc}
\hline & $\begin{array}{l}\text { Pigment } \\
\text { first observed } \\
\text { (age, in days) }\end{array}$ & $\begin{array}{l}\text { Pattern } \\
\text { completed } \\
\text { (age, in days) }\end{array}$ \\
\hline $\begin{array}{l}\text { 1. White }(n=2) \\
\text { 3. Red "U" }\end{array}$ & $5-10$ & $10-20$ \\
posterior $(n=1)$ & $10-20$ & $15-30$ \\
$\begin{array}{l}\text { 4. Red "U" } \\
\text { anterior }(n=5)\end{array}$ & $20-30$ & $25-40$ \\
$\begin{array}{l}\text { 6. Red "U" anterior } \\
\text { and posterior }(n=5)\end{array}$ & $25-35$ & $30-45$ \\
$\begin{array}{l}\text { 7. Red ring }(n=1) \\
\text { 8. Red over entire } \\
\text { abdomen }(n=2)\end{array}$ & $40-60$ & $70-100$ \\
\hline
\end{tabular}

margins. The red areas grew steadily into the final form of the pattern, which lacked the black border.

The offspring of only a single female with a red ring pattern were found. These did not show any colour until approximately 50 days, after which the red ring grew from two black-bordered red patches at the anterior margins of the abdomen. The offspring of a female with an entirely red abdomen, on the other hand, developed patches of black on the anterior margin of the abdomen only about 15 days after hatching. These grew steadily, to form a black ring, which thickened to cover the whole abdomen, and then started to turn red (from the margins inwards) as the animals reached maturity. Overall, the total time to completion of pigment deposition in a particular pattern was roughly proportional to the amount of red in that pattern.

\section{Inheritance of the different morphs}

Phenotype ratios were: (a) a single type in 12 broods; (b) an approximate 1:1 ratio in 13 broods; (c) a 3:1 ratio in 1 brood; and (d) an approximate $1: 1: 1: 1$ ratio in one brood (table 3 ). All progeny ratios were consistent with inheritance controlled by simple Mendelian alleles at one locus.

The mode of inheritance was analyzed by considering morphs, for simplicity, in two categories only: unpatterned or patterned. The dominance relationship between alleles controlling unpatterned and patterned morphs was not clear from examination of individual broods. For example, the progeny of females 1 through 11 exhibit the maternal phenotype only. This could be explained if the female were either: (i) homozygous for a recessive unpatterned allele and mated with a homozygous recessive unpatterned male; or (ii) if either parent were heterozygous for a dominant unpatterned allele and mated with a homozygous unpatterned spider.

The nature of the dominance was elucidated by assuming a Hardy-Weinberg equilibrium. Counting mature spiders only, expected morph frequencies were calculated (table 4). Because the father could not be determined for any given brood, we assumed that mating occurred at random with respect to morph type. The table compares the expected and observed proportions of patterned morphs in broods, if: (a) unpatterned is dominant (for unpatterned mothers, $\chi^{2}=10 \cdot 7$, $\mathrm{df}=2, P<0.01 ;$ for patterned mothers, $\chi^{2}=9 \cdot 2$, $\mathrm{df}=2, P=0.01$ ); and (b) if unpatterned is recessive (for unpatterned mothers, $\chi^{2}=0 \cdot 4, \mathrm{df}=2, P>$ 0.70 ; for patterned mothers, $\chi^{2}=3 \cdot 5, \mathrm{df}=2, P>$ $0 \cdot 15)$. These results support the hypothesis that unpatterned is under the control of a recessive allele. Patterned morphs, as a whole, are dominant.

The 1:1:1:1 offspring ratio of female (27), (table 3 ) shows that more than two alleles affect colour. The simplest explanation for this pattern assumes a single locus, with both parents 
Table 3 Morph frequencies of the offspring of individual females. $0=$ unpatterned; $1=$ opaque white; 2 red patches on posterior dorsum of abdomen only; $3=$ red " $U$ " on posterior dorsum; $4=$ red " $U$ " on anterior dorsum; $5=$ red lines; $6=$ red " $U$ " on anterior and posterior dorsum; $7=$ ring encircling abdomen; $8=$ entire abdomen pigmented

\begin{tabular}{|c|c|c|c|c|c|c|c|c|c|c|c|}
\hline \multicolumn{2}{|c|}{ Mother } & \multirow{2}{*}{$\begin{array}{l}\text { Offspring } \\
(N)\end{array}$} & \multicolumn{9}{|c|}{ Morph of offspring } \\
\hline No. & Morph & & 0 & 1 & 2 & 3 & 4 & 5 & 6 & 7 & 8 \\
\hline 1 & 0 & 31 & 31 & & & & & & & & \\
\hline 2 & 0 & 7 & 7 & & & & & & & & \\
\hline 3 & 0 & 6 & 6 & & & & & & & & \\
\hline 4 & 0 & 30 & 30 & & & & & & & & \\
\hline 5 & 0 & 15 & 15 & & & & & & & & \\
\hline 6 & 0 & 12 & 12 & & & & & & & & \\
\hline 7 & 0 & 8 & 8 & & & & & & & & \\
\hline 8 & 0 & 5 & 5 & & & & & & & & \\
\hline 9 & 0 & 41 & 41 & & & & & & & & \\
\hline 10 & 0 & 8 & 8 & & & & & & & & \\
\hline 11 & 0 & 9 & 9 & & & & & & & & \\
\hline 12 & 0 & 8 & & & & & 8 & & & & \\
\hline
\end{tabular}

Offspring in $1: 1$ ratio

\begin{tabular}{|c|c|c|c|c|c|c|c|c|c|c|c|}
\hline \multicolumn{2}{|c|}{ Mother } & \multirow{2}{*}{$\begin{array}{l}\text { Offspring } \\
(N)\end{array}$} & \multicolumn{9}{|c|}{ Morph of offspring } \\
\hline No. & Morph & & 0 & 1 & 2 & 3 & 4 & 5 & 6 & 7 & 8 \\
\hline 13 & 0 & 26 & 14 & & & & & & 12 & & \\
\hline 14 & 0 & 17 & 8 & & & & 9 & & & & \\
\hline 15 & 0 & 7 & 3 & & & & 4 & & & & \\
\hline 16 & 0 & 27 & 14 & & & & & 13 & & & \\
\hline 17 & 0 & 15 & 7 & & & 8 & & & & & \\
\hline 18 & 1 & 23 & 12 & 11 & & & & & & & \\
\hline 19 & 4 & 8 & 4 & & & & 4 & & & & \\
\hline 20 & 6 & 48 & 25 & & & & & & 23 & & \\
\hline 21 & 6 & 28 & 13 & & & & & & 15 & & \\
\hline 22 & 6 & 9 & 4 & & & & & & 5 & & \\
\hline 23 & 7 & 11 & 5 & & & & & & & 6 & \\
\hline 24 & 7 & 10 & 4 & & & & & & & 6 & \\
\hline 25 & 8 & 30 & 14 & & & & & & & & 16 \\
\hline
\end{tabular}

Offspring in $3: 1$ or $1: 1: 1: 1$ ratios

\begin{tabular}{|c|c|c|c|c|c|c|c|c|c|c|c|}
\hline \multicolumn{2}{|c|}{ Mother } & \multirow{2}{*}{$\begin{array}{l}\text { Offspring } \\
(N)\end{array}$} & \multicolumn{9}{|c|}{ Morph of offspring } \\
\hline No. & Morph & & 0 & 1 & 2 & 3 & 4 & 5 & 6 & 7 & 8 \\
\hline 26 & 7 & 16 & 4 & & & & & & & 12 & \\
\hline 27 & 2 & 20 & 6 & & 4 & & & & 5 & 5 & \\
\hline
\end{tabular}

heterozygous. In this scenario, the female would have had a dominant allele for her pattern (red patches on posterior dorsum), and a recessive one for unpatterned. The male would have had a different dominant allele for his pattern, and a recessive unpatterned allele.

\section{DISCUSSION}

The results indicate that the predominant morph was unpatterned (translucent yellow). The patterned morphs exhibit ontogenetic changes, the extent of the pattern dictating the period over 
Table 4 Tests for dominance of alleles controlling colour pattern. Expected frequencies were calculated from the overall morph frequencies shown in table 1, assuming Hardy-Weinberg equilibrium

\begin{tabular}{lllll}
\hline \multirow{2}{*}{ Mother } & Brood type & Dominant & $\begin{array}{l}\text { Expected frequency } \\
\text { if unpatterned is }\end{array}$ & \\
\cline { 3 - 5 } Unpatterned & All unpatterned & 0.35 & 0.62 & 0.65 \\
& 3/4 unpatterned & 0.36 & 0.00 & 0.00 \\
& $1 / 2$ unpatterned & 0.29 & 0.33 & 0.29 \\
& O unpatterned & 0.00 & 0.04 & 0.06 \\
Patterned & All unpatterned & 0.15 & 0.00 & 0.00 \\
& $1 / 2$ unpatterned & 0.47 & 0.55 & 0.80 \\
& $1 / 4$ unpatterned & 0.00 & 0.29 & 0.20 \\
& 0 unpatterned & 0.38 & 0.16 & 0.00 \\
\hline
\end{tabular}

which this occurs. Information to date points to the ommochrome xanthommatin as being responsible for most pigmentation in spiders (Seligy, $1969,1971,1972)$. The development of red pigment in $T$. grallator may be related to the redox state of the pigment; changes in the redox state of xanthommatin can produce a range of colours from red to black, as well as yellow (Seligy, 1972). Information on E. ovata indicates that this spider also develops black pigments, which tend to be deposited earlier in its development than the red (Reillo and Wise, 1988b).

In $T$. grallator, black pigment may be a precursor of red. Patterns in spiderlings are often seen initially as black, turning red in later instars. The effect is more pronounced, and sustained over longer periods, in the more heavily patterned morphs. This suggests that the period over which pigment is deposited is a function of the allele determining colour pattern.

A similar idea has been proposed by Hippa and Oksala (1979) to explain the different times of pigment deposition in E. ovata. For this species, however, there is a simpler explanation: Oxford (1983) proposed a regulatory locus determining whether pigment is deposited early or late in the development of an individual. This time of deposition is coded by an allele at a different locus from that determining the colour. Unlike $E$. ovata, however, the different patterns of $T$. grallator appear to differ in the times at which colour is first observed, and periods over which ontogenetic changes occur. A regulatory locus is not the simplest explanation in this situation.

Mature animals of each sex of $T$. grallator exhibit similar morph types and frequencies (table 1 ), a result which is contrary to the findings of Gon (see Stamps and Gon, 1983). The only four morphs that suggest any difference between the sexes (red over the entire abdomen, opaque white, red patches and red " $U$ " on the posterior dorsum) were very uncommon, and the sample size was too small to detect differences. With the possible exception of these morphs, patterns appear not to be sex limited. This result is similar to what has been found in populations of E. ovata in which the "early" regulatory allele is fixed. The situation for E. ovata is, however, complicated by the presence of the "late" regulatory allele which causes sex limitation of certain patterns.

There are other similarities between the colour polymorphism exhibited by $T$. grallator and that of $E$. ovata. First, the most frequent morph in both systems is yellow (Oxford, 1976; Wise and Reillo, 1985; Reillo and Wise, 1988c). Also, the less frequent red morphs have two patterns which exhibit similar configurations of red. The unpatterned morph in $T$. grallator corresponds with the lineata morph in $E$. ovata; the red longitudinal lines in $T$. grallator with the redimita morph in $E$. ovata; the red over the entire abdomen in $T$. grallator with ovata. The results above indicate that the similarity extends to the mode of inheritance. The polymorphism $T$. grallator appears to be inherited through simple Mendelian alleles, with the unpatterned morph under the control of an allele that is recessive to alleles for patterned morphs, as in E. ovata (Hippa and Oksala, 1979; Oxford, 1983; Oxford, 1985; Reillo and Wise, $1988 a$ ).

If the similarity to $E$. ovata is extended to the various patterned morphs, these are likely to be affected by a dominance hierarchy of alleles at the same locus rather than the interaction of alleles at different loci. Only limited evidence for this can be found, through the $1: 1: 1: 1$ offspring ratio of 
female (27). The most likely explanation for this situation is that the patterned alleles exhibit partial dominance, with the phenotype depending on the combination of the patterned alleles present. The small amount of red on this female may be due to an allele that is dominant to unpatterned, and interacts with all other patterned alleles to produce other patterned phenotypes. It may be that the extent of red pigment deposition for which an allele codes is proportional to the dominance of that allele. Although our results are readily explained using a single locus with many alleles, the possibility of two or more loci interacting to determine colour pattern cannot be excluded.

The results show that abdominal colour in $T$. grallator is inherited as a simple Mendelian character, with unpatterned morphs recessive to patterned morphs. Moreover, morphs accumulate pigment (initially black, changing to red) over a time period that is roughly proportional to the amount of red in the final pattern. This study is one of the few to examine the ontogeny and inheritance of polymorphism in spiders. Because of the range of patterns exhibited and the way in which they develop, this system presents an ideal opportunity for analyzing the origins and maintenance of chromatic polymorphisms.

Acknowledgements The study was inspired and instigated through the work of Dr Sam Gon. It would have been quite impossible without an enormous amount of help from the Nature Conservancy of Hawaii: Rob Rydell encouraged the initial efforts; Alan Holt, Paul Higashino and Mark White allowed progress to continue throughout the year. Dr Lloyd Loope and Art Medeiros (Haleakala National Park) gave immense support and encouragement throughout the study. Thanks also to Bill Mull and Geoff Oxford for invaluable advice and discussion and to Dr John Bordley and the University of the South for use of computer equipment. Dr Chris Parrish helped in completion of the study. The work was funded by Whitehall Foundation grant J86-47, with additional support from the Nature Conservancy of Hawaii and the National Park Service.

\section{REFERENCES}

BISHOP, J, A. AND COOK, L. M. 1980. Industrial melanism and the urban environment. Adv. Ecol. Res., 11, 373-404.

BLANDIN, P. 1977. Etudes sur les Pisauridae africaines, VIII. Les genres Chiasmopes Pavessi, 1883 et Rothus Simon, 1898 (Araneae, Pisauridae, Pisaurinae). Rev. Zool. afr., 91(3), 538-557.

BRADY, A. R. 1964. The lynx spiders of North America, north of Mexico (Araneae: Oxopidae). Bull. Mus. Comp. Zool. Harv., 131, 429-518.

CLARKE, B., ARTHUR, W. HORSLEY, D. T. AND PARKIN, D. T. 1978. Genetic variation and natural selection in pulmonate molluscs. In Fretter, J. and Peake, J. (eds.) Pulmonates, Vol. 2A, Systematics, Evolution and Ecology, Academic Press, London.
Comstock, J. H. 1948. The Spider Book, rev. edn. by Gertsch, W. J. Comstock Publ. Comp. Inc., Ithaca, New York.

DAVIES, V. T. AND RAVEN, R. J. 1980. Megadolomedes nov. gen. (Araneae: Pisauridae) with a description of the male of the type-species, Dolomedes australianus Koch. Mem. Qd. Mus., 20(1), 135-141.

EMERIT, M. 1969. Contribution a l'etude des Gasteracanthes (Araneides, Argiopides) de Madasgascar et des Iles Voisines. Thes, Univ. Montpellier AO-2888, p1-434.

EMERIT, M. 1969. Contribution a l'etude des Gasteracanthes (Araneides, Argiopides) de Madasgascar et des Iles Voisines. Thes, Univ. Montpellier AO-2888, pp. 1-434.

FORD, E. B. 1975. Ecological Genetics, 4th edn. Chapman and Hall, London.

Galiano, M. E. 1981. Revision del genero Phiale C. L. Koch, 1946 (Araneae, Salticidae) III. Las especes polimorficas del grupo mimica. J. Arachnol., 9, 61-85.

GON, S. M. III. 1985. Comparative Behavioural Ecology of the Spider Theridion grallator Simon, (Araneae: Theridiidae) in the Hawaiian Archipelago. Ph.D. Dissertation, U.C. Davis.

GUNNARSSON, B. 1987. Phenotypic variation in dark coloration in Pityohyphantes phyrigianus (C. L. Koch) (Araneae: Linyphiidae). Bull. Brit. Arachnol. Soc., 6(9), 369-374.

HIPPA, H. AND I. OKSALA. 1979. Colour polymorphism of Enoplognatha ovata (Clerck) (Araneae: Theridiidae) in western Europe. Hereditas, 90(2), 203-212.

LEVI, H. W. 1981. The American orb-weaver genus Dolichognatha and Tetragnatha north of Mexico (Araneae: Araneidae, Tetragnathinae). Bull. Mus. Comp. Zool. Harvard, $149(5), 271-318$.

LOCKET, G. H. AND MILlidge, A. F. 1951. British Spiders, Vol. 1. Roy Soc., London.

MARETIC, Z. 1965. Latrodectus and Latrodectismus. Nat. Mus., $95,124-132$.

MAYR, E. 1970. Populations, Species and Evolution: An Abridgement of Animal Species and Evolution. Belknap Press of Harvard University Press, Cambridge, Mass.

OXFORD, G.S. 1976. The colour polymorphism in Enoplognatha ovatum (Clerck) (Araneae: Theridiidae). Heredity, 36, 369381.

OXFORD, G. S. 1983. Genetics of colour and its regulation during development in the spider Enoplognatha ovata (Clerck) (Araneae: Theridiidae). Heredity, 51, 621-634.

OXFORD, G. S. 1985. Geographical distribution of phenotypes regulating pigmentation in the spider Enoplognatha ovata (Clerck) (Araneae: Theridiidae). Heredity, 55, 37-45.

PLATNICK, N. I. AND SHADAB, M. V. 1975. A revision of the spider genus Gnaphosa (Araneae, Gnaphosidae) in America. Bull. Am. Mus. Nat. Hist., 155(1), 1-66.

REILLO, P. R. AND WISE, D. H. $1988 a$. An experimental evaluation of selection on color morphs of the polymorphic spider Enoplognatha ovata (Araneae: Theridiidae). Evolution, 42, 1172-1189.

REILLO, P. R. AND WISE, D. H. 1988b. Temporal and spatial patterns of morph frequency variation among coastal Maine populations of the polymorphic spider Enoplognatha ovata (Araneae: Theridiidae). Am. Mid. Nat., 119, 337-354.

REILLO, P. R. AND WISE, D. H. 1988c. Genetics of color expression in the spider Enoplognatha ovata (Araneae: Theridiidae) from coastal Maine. Am. Mid. Nat., 119318 326.

SELIGY, V. L. 1969. Biochemical aspects of pigment variation in the spider Enoplognatha ovata (Clerck) (Araneae: Theridiidae). Can. J. Zool., 47, 1103-1105.

SELIGY, V. L. 1971. Postembryonic development of the spider Enoplognatha ovata (Clerck). Zool. J. Linn. Soc., 50, 21-31. 
SEligy, V. L. 1972. Ommochrome pigments of spiders. Comp. Biochem. Physiol., 42A, 699-709.

STAMPS, J. A. AND GON, S. M. 1983. Sex-biased variation in the prey of birds. Ann. Rev. Ecol. Syst., 14, 231-253.

TURNER, J. R. G. 1977. Butterfly mimicry: the genetical evolution of an adaptation. In Hecht, M. K., Steere, W. C. and Wallace, B. (eds.) Evolutionary Biology, Vol. 10, Plenum Press, New York.
WISE, D. H. AND REILlo, P. R. 1985. Frequencies of color morphs in four populations of Enoplognatha ovata (Araneae: Theridiidae) in eastern North America. Psyche, 92, 135-144.

YAGINUMA, T. 1986. Spiders of Japan in Color. Hoikushu Publishing Company, Osaka, Japan. 